\title{
The Importance of Physiological Limits in Determining Biogeographical Range Shifts due to Global Climate Change: The Heat-Shock Response
}

\begin{abstract}
Lars Tomanek ${ }^{\star}$
Center for Coastal Marine Sciences and Environmental Proteomics Laboratory, Department of Biological Sciences, California Polytechnic State University, San Luis Obispo, California 93407
\end{abstract}

Accepted 5/16/2008; Electronically Published 10/9/2008

\begin{abstract}
Physiological processes that set an organism's thermal limits are in part determining recent shifts in biogeographic distribution ranges due to global climate change. Several characteristics of the heat-shock response (HSR), such as the onset, maximal, and upper limit of heat-shock protein (Hsp) synthesis, contribute to setting the acute upper thermal limits of most organisms. Aquatic animals from stable, moderately variable, or highly variable thermal environments differ in their HSR. Some animals living in extremely stable thermal environments lack the response altogether. In contrast, rocky intertidal animals that experience highly variable thermal conditions start synthesizing Hsps, that is, the onset of synthesis, below the highest temperatures that they experience. Thus, these organisms experience thermal conditions in their environment that are close to the upper thermal limits in which they can defend themselves against cellular thermal insults by employing the HSR. Subtidal animals are characterized by moderately variable thermal environments, and their cells start synthesizing Hsps above the highest temperatures that they experience. The upper thermal limits against which they can defend themselves are thus much higher than the highest body temperatures they currently experience. Furthermore, the ability to acclimate to changing thermal conditions seems greatest among animals from moderately variable environments and limited in animals from stable and highly variable environments. Thus, these findings suggest that organisms with the narrowest (stenothermal) and the widest (highly eurythermal) temperature tolerance ranges live closest to their thermal limits
\end{abstract}

*E-mail: ltomanek@calpoly.edu.

Physiological and Biochemical Zoology 81(6):709-717. 2008. (C) 2008 by The University of Chicago. All rights reserved. 1522-2152/2008/8106-8046\$15.00 DOI: $10.1086 / 590163$ and have a limited ability to acclimate, suggesting that they will be most affected by global climate change.

\section{Introduction}

Global climate change is causing many organisms to shift their biogeographic distribution ranges (Barry et al. 1995; Walther et al. 2002; Root et al. 2003; Harley et al. 2006; Parmesan 2006). Physiological processes that set thermal tolerance limits are thought to determine or at least contribute to some of the shifts that have been observed. Although very few studies have directly linked physiological tolerance limits to current range shifts (Pörtner and Knust 2007), a number of studies have estimated the temperature difference that correlates with adaptive variation between closely related organisms found in different geographic areas in protein thermal stability, enzyme kinetic properties, membrane composition, gene and protein expression, and heart rate function (Hochachka and Somero 2002). Thus, we are able to estimate the minimal amount of change in average or maximal temperature that is necessary for natural selection to act on physiological processes.

In addition to evolutionary comparisons, physiological studies on two other timescales-hours to several days and weeks to months-have provided us with insights into how animals cope with acute and chronic heat stress. By exposing animals to acute stress (hours to several days), we can compare the range over which a physiological stress response is observed with the actual body temperatures animals experience under field conditions. Such experiments provide an estimate of the risk that an animal will experience temperatures that are close to or even above a critical threshold, such as protein denaturing conditions. Although such thresholds can shift under chronic stress or acclimation, in general they indicate that those temperatures are stressful and are likely to be energetically costly, thereby affecting fitness and presumably causing range shifts (a chain of causal events that cannot be covered in detail in this perspective).

Recent predictions of the increase in future temperatures due to global climate change indicate that such physiological thresholds have already been reached (IPCC 2007). Because I am focusing on marine organisms, it is important to mention that global ocean temperatures have increased less than air temperatures due to the greater heat capacity of water (IPCC 2007; Sutton et al. 2007). Between 1961 and 2003, the world oceans 
have warmed by about $0.1^{\circ} \mathrm{C}$ (with a range of $0.0^{\circ}-0.5^{\circ} \mathrm{C}$, depending on depth) and have absorbed $84 \%$ of the observed warming at the global level (Levitus et al. 2005; IPCC 2007). Ocean basins differ in the degree of warming and the depth to which warming has penetrated (Barnett et al. 2005; Pierce et al. 2006). Most of the warming has occurred in the top 300 m. Using a multimodel ensemble (IPCC 2007), it has been predicted that ocean temperatures will increase between $0.5^{\circ}$ and $2.5^{\circ} \mathrm{C}$ by the end of the twenty-first century. Air temperatures over the oceans are projected to increase between $1.4^{\circ}$ and $3.9^{\circ} \mathrm{C}$ (IPCC 2007) over the next $80 \mathrm{yr}$. Although many uncertainties still exist about the projected change in ocean and coastal temperatures, intensity, frequency, and duration of heat waves are predicted to increase (IPCC 2007) and are likely to affect near-shore coastal environments such as intertidal zones. Given the current status of our knowledge, there is no evidence for a future change in the variability or amplitude of the El Niño Southern Oscillation (IPCC 2007). Prolonged warmer time periods over weeks or months will be accompanied by acute extremes, and thus, this scenario will resemble studies in which physiologists conduct (laboratory) acclimations or (field) acclimatizations that are followed by acute exposures to heat stress. In order to better understand how marine organisms will respond to global climate change, researchers will need to determine the capacity of organisms to cope with increasing temperatures specifically by describing the extent to which organisms can modify acute responses while adjusting to changing temperature conditions over longer time periods-an animal's acclimatization or acclimation ability. Interestingly, the longheld assumption that more eurythermal organisms are also characterized by a greater ability to acclimate has being challenged by several recent studies.

Here, I will focus on studies that have investigated the relationships among the body temperatures that marine organisms experience in the field, their acute heat-shock (or stress) response (HSR), and their ability to modify the response following acclimation in the laboratory or acclimatization in the field. I then will present the hypothesis that organisms from environments that vary widely in thermal tolerance will be affected differently by an increase in temperature, as is predicted to occur due to global climate change.

\section{The Heat-Shock Response: Background}

The HSR is characterized by the preferential and highly induced synthesis of heat-shock proteins (Hsps), a group of molecular chaperones, in response to heat and other stressors and has been found to be particularly important for coping with thermal stress (Feder and Hofmann 1999; Hoffmann et al. 2003). The importance of molecular chaperones for thermal tolerance is due to the thermal sensitivity of protein conformation (Somero 1995; Feige et al. 1996; Frydman 2001; Hartl and HayerHartl 2002; Somero 2004). Under nonstressful conditions, Hsps act as molecular chaperones and bind to newly synthesized polypeptides to keep them in folding-competent conforma- tions. Under stressful conditions, Hsps bind to hydrophobic side chains that are exposed as thermally sensitive proteins begin to unfold. Hsps thus initially stabilize the unfolding protein, preventing further denaturation. Then Hsps assist the protein to refold to its native conformation. If folding is not possible, Hsps help ensure that irreversibly damaged proteins enter the cell's proteolytic cycle. In sum, Hsps are important folding catalysts for protein maturation under nonstressful conditions and are stabilizers of protein integrity under acute stress conditions. Under both conditions, Hsps play a key role in controlling protein homeostasis and are among the main indicators of stress-induced protein damage.

\section{Variation in the Heat-Shock Response}

A number of studies have shown that closely related organisms that occupy different thermal niches vary in their HSR after acclimation to common thermal conditions (Ushakov et al. 1977; Sanders et al. 1991; Dietz and Somero 1993; Hofmann and Somero 1996a; Tomanek and Somero 1999, 2000, 2002; Nakano and Iwama 2002; Sorte and Hofmann 2005). Furthermore, it has been established that the HSR can vary according to the thermal history of an organism. For example, acclimatization to seasonal temperature changes can modify the onset temperature $\left(T_{\text {on }}\right)$ of the stress response in intertidal bivalves such as Mytilus californianus (Roberts et al. 1997) and Crassostrea gigas (Hamdoun et al. 2003). Of particular interest have been the questions of how eurythermal and stenothermal species differ in their HSR and how acclimation of Hsp synthesis varies. The comparison of closely related species within a genus (congeners) has been shown to be a well-suited approach to address these questions (Sanders et al. 1991; Dietz and Somero 1993; Leroi et al. 1994; Hofmann and Somero 1996a; Tomanek and Somero 1999, 2000, 2002; Nakano and Iwama 2002; Tomanek 2002; Sorte and Hofmann 2005). For example, differences have been found in the ability of eurythermal and stenothermal congeneric snail species of the genus Tegula (recently renamed Chlorostoma; Carlton 2007) to shift $T_{\text {on }}$ after acclimation to elevated temperatures (Tomanek and Somero 1999). The low-intertidal to subtidal congeners but not the mid- to low-intertidal congeners showed a shift in $T_{\text {on }}$ toward higher temperatures with increasing acclimation temperature. Although the explanations for such interspecific variations in the acclimatory plasticity of the response are complex, acclimation-induced modifications of Hsp synthesis within a species can be in part explained by the cellular thermometer model of the transcriptional regulation of Hsp expression (Dietz and Somero 1992; Roberts et al. 1997; Tomanek and Somero 2002). Attempts to characterize the underlying mechanisms and specifically the transcriptional regulatory steps that change during the modification of the onset of the HSR have been few (Buckley et al. 2001; Tomanek and Somero 2002). Among the factors that have been proposed to be important is heat-shock transcription factor 1 (HSF1), whose activity is normally repressed under nonstressful conditions through 
binding to a chaperone complex that consists of several Hsps (Morimoto 1998). Under stressful conditions, these chaperones bind to unfolding proteins instead and thus release HSF1 to activate Hsp transcription.

Ecologists who are interested in assessing the degree to which environmental stress limits species' distributions have regarded Hsps as useful indicators to quantify the stress levels organisms experience under natural conditions. However, very little is known about the temporal variation of Hsp levels following thermal stress (Hofmann and Somero 1995, 1996b; Tomanek and Somero 2000; Nakano and Iwama 2002; Todgham et al. 2006). Although it is tempting to assume the adaptive importance of the interspecific variation in the HSR in species that occupy environments of widely varying thermal characteristics, there are very few studies that have actually demonstrated this assumption under field conditions (Tomanek and Sanford 2003). Hsp expression also varies over narrow to broad spatial scales. For example, variation has been found due to orientation-that is, the angle of the rock face of mussels at one site in the intertidal zone (Helmuth and Hofmann 2001) — between two sites in Oregon that are only $30 \mathrm{mi}$ away from each other (Halpin et al. 2002) and between populations that are hundreds of miles apart (Sorte and Hofmann 2004; Osovitz and Hofmann 2005; Sagarin and Somero 2006).

Despite limitations in testing the adaptive significance of variability in the HSR, several of the comparative studies cited above provide insights not only into the cellular properties that limit temperature tolerance but also into how global climate change may differently affect species from environments of varying thermal characteristics. Together, the results of these studies lead to the hypothesis I present here, that organisms from environments characterized by either stable or highly variable temperatures will be more affected by global climate change than organisms from environments of only moderate thermal variation.

\section{The Heat-Shock Response and an Animal's Temperature Range}

The above hypothesis may best be illustrated by using studies of the HSR (for a broader meta-analysis of HSR studies, see Barua and Heckathorn 2004). Antarctic fish represent one extreme because their environment is very stable, and they rarely or never experience thermal stress. Antarctic fish of the suborder Notothenioidei are known for their unique adaptations to a stably cold environment (e.g., antifreeze proteins; Petricorena and Somero 2007) and for having lost physiological functions to cope with a thermally fluctuating environment (e.g., absence of Hsp synthesis in response to acute heat stress; Hofmann et al. 2000). The existence of an HSR in response to acute temperature stress is almost ubiquitous among animals, and its absence in antarctic fish is remarkable. The lack of a response is most likely a consequence of the very stable environment that these fish have evolved in over the past $14 \mathrm{~m} . \mathrm{yr}$., since it has been shown that the response is induced in their cold-temperate New Zealand relatives upon heat stress (Hofmann et al. 2005). Thus, any physiological response in Notothenioids to an increase in Antarctic Ocean temperatures due to global warming will have to do without this important cellular defense mechanism. However, antarctic fish synthesize Hsps constitutively, that is, as molecular chaperones (Hofmann et al. 2005), and it is possible that, depending on the rate of warming, upregulation of constitutive levels of Hsps may enable these fish to adapt.

Another example of evolutionary variation in the HSR is found in the freshwater cnidarian species Hydra oligactis, which was shown to lack an HSR and to be extremely sensitive to minor thermal variations (Bosch et al. 1988; Gellner et al. 1992). Its congener Hydra vulgaris, in contrast, tolerates a greater thermal range, shows inducible thermal tolerance after Hsp synthesis, and copes well with thermal variation. Among marine fish, several temperate species that occur in environments in the midrange of thermal variability have been shown to have robust HSRs. The short-term variation in temperature and a moderately wide ecological temperature range correlate with an onset temperature of the HSR that is just above frequently experienced body temperatures (Dietz and Somero 1993; Zakhartsev et al. 2005). Fish and invertebrates from the rocky intertidal, however, experience extreme thermal variations (Dietz and Somero 1992; Helmuth 1999) and will activate the response at temperatures that they frequently experience under natural conditions (Sanders et al. 1991; Hofmann and Somero 1995). In other words, data from recent studies indicate that species experiencing a very narrow (or stable) thermal range (both short-term and over their distribution range) may either not have the HSR or rarely activate it. In contrast, species from environments with high variability in temperature (over a short time period) can and do activate the HSR within the upper range of temperatures they experience. Finally, organisms from moderately variable thermal environments induce the HSR rarely if ever and only at temperatures above those they commonly experience (Fig. 1). Thus, organisms from thermal environments that are highly variable have maximized the temperature range that they can occupy by recruiting the protective power of the HSR, and any further increase in habitat temperature is going to push these organisms beyond the thermal range they can tolerate, potentially forcing range shifts, range contractions, or, in the worst case, extinction. Alternatively, intrinsic (e.g., primary sequence) and extrinsic (e.g., compatible osmolytes) factors may stabilize proteins and thereby extend the thermal range an organism is able to occupy (Hochachka and Somero 2002; Yancey 2005; Burg and Ferraris 2008). The evolutionary forces that favor one over the other scenario are complex and require a broader comparison than can be given here. Organisms from stable thermal environments are not adapted (or are very limited in their ability) to cope with an increase in temperature. Therefore, these two groups face the greatest threat from global warming. In contrast, animals from environments with limited variability will be able to extend their thermal range because the HSR is activated at tempera- 


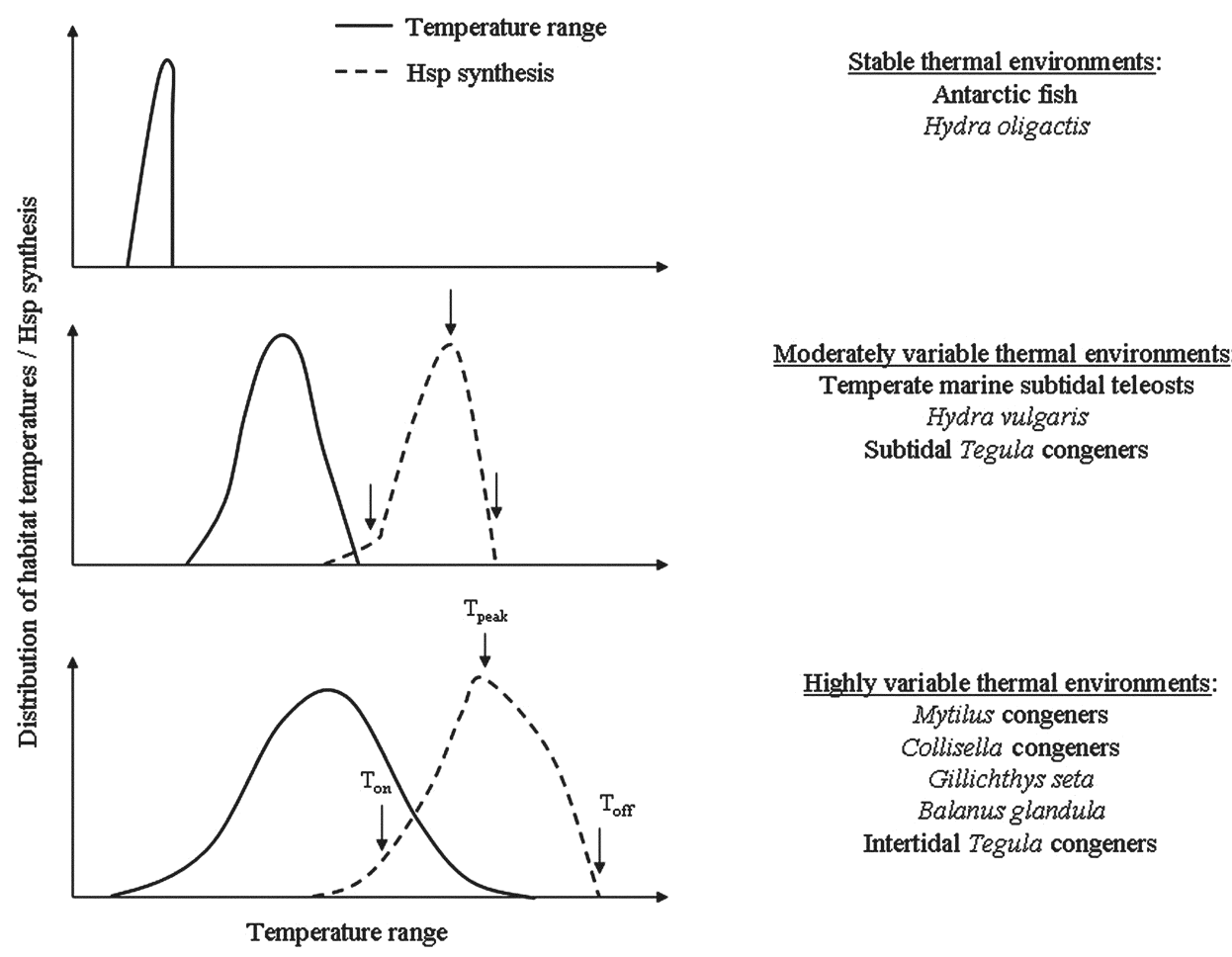

Figure 1. Comparison of temperature range and thermal range of heat-shock protein (Hsp) synthesis in aquatic (mostly marine) animals from stable, moderately variable, and highly variable thermal environments (for citations, see text); $T_{\text {on }}$ indicates the onset temperature, $T_{\text {peak }}$ indicates the temperature of maximal induction, and $T_{\text {off }}$ indicates the cessation temperature of Hsp synthesis.

tures above their current typical body temperatures and therefore can protect them from increasing temperatures. However, because I have based my conclusion mainly on marine and not terrestrial organisms, it may be possible that there are eurythermal species that do not live close to their lethal temperatures under natural conditions and can evolve to tolerate higher temperatures.

\section{Acclimation Ability of the Heat-Shock Response and Thermal Tolerance}

Eurythermal species may not simply be living closer to temperatures that induce an HSR; their ability to acclimate may also be limited in part because they may not be able to further adjust to temperatures even higher than the ones with which they are already coping. To test this hypothesis, we examined three temperate marine snail species of the genus Tegula that occupy the subtidal and intertidal zone of rocky shores along the Pacific Coast in California, environments with differing degrees of thermal variability. Of the three species we examined, Tegula funebralis occurs highest, from the mid- to the lowintertidal zone, and relative to low-intertidal and subtidal species, experiences greater maximum temperatures (up to at least $\left.33^{\circ} \mathrm{C}\right)$ as well as greater changes in body temperatures $\left(19^{\circ} \mathrm{C}\right.$ within a tidal cycle) due to frequent emersion during low-tide periods (Riedman et al. 1981; Tomanek and Somero 1999). Tegula brunnea and Tegula montereyi occur farther down, from the low-intertidal to the subtidal zone, and are rarely exposed to air and thus experience lower $\left(<24^{\circ} \mathrm{C}\right)$ and less variable $\left(\sim 7^{\circ} \mathrm{C}\right.$ range) body temperatures than $T$. funebralis.

We acclimated individuals of each species to $13^{\circ}, 18^{\circ}$, and $23^{\circ} \mathrm{C}$, a range extending from the middle of the subtidal species' habitat temperature range up to a temperature experienced by T. funebralis only during emersion. After acclimation to $13^{\circ} \mathrm{C}$, the preferential and strongly enhanced synthesis of several proteins with a molecular mass of $70-71,77-78$, and $88-90 \mathrm{kDa}$ became apparent in all species with increasing incubation temperature as evidenced by one- and two-dimensional gel electrophoresis. Hsp70 was the most highly expressed of these proteins (Figs. 2, 3; Tomanek and Somero 1999; Tomanek 2005). After the $13^{\circ} \mathrm{C}$ acclimation, the low-intertidal to subtidal $T$. brunnea and T. montereyi showed a lower $T_{\text {on }}$ of Hsp70 synthesis than snails of the midintertidal T. funebralis $\left(24^{\circ}\right.$ vs. $\left.27^{\circ} \mathrm{C}\right)$. In addition, both subtidal species showed lower temperatures of maximal Hsp70 synthesis $\left(T_{\text {peak }}\right)$ and the upper thermal limits of Hsp70 synthesis $\left(T_{\text {off }}\right)$. Thus, $T_{\text {on }}, T_{\text {peak }}$, and $T_{\text {off }}$ were consistently lower in the more heat-sensitive subtidal species in comparison with the heat-tolerant, midintertidal zone species T. funebralis (Fig. 2). In addition, the $T_{\text {on }}$ 's in T. brunnea and T. monterey $i$ were above the temperature range these congeners normally experience; the $T_{\text {on }}$ of $T$. funebralis, however, was at least $6^{\circ} \mathrm{C}$ below the highest temperatures it experiences.

After $18^{\circ}$ (data not shown) and $23^{\circ} \mathrm{C}$ acclimation, we eval- 


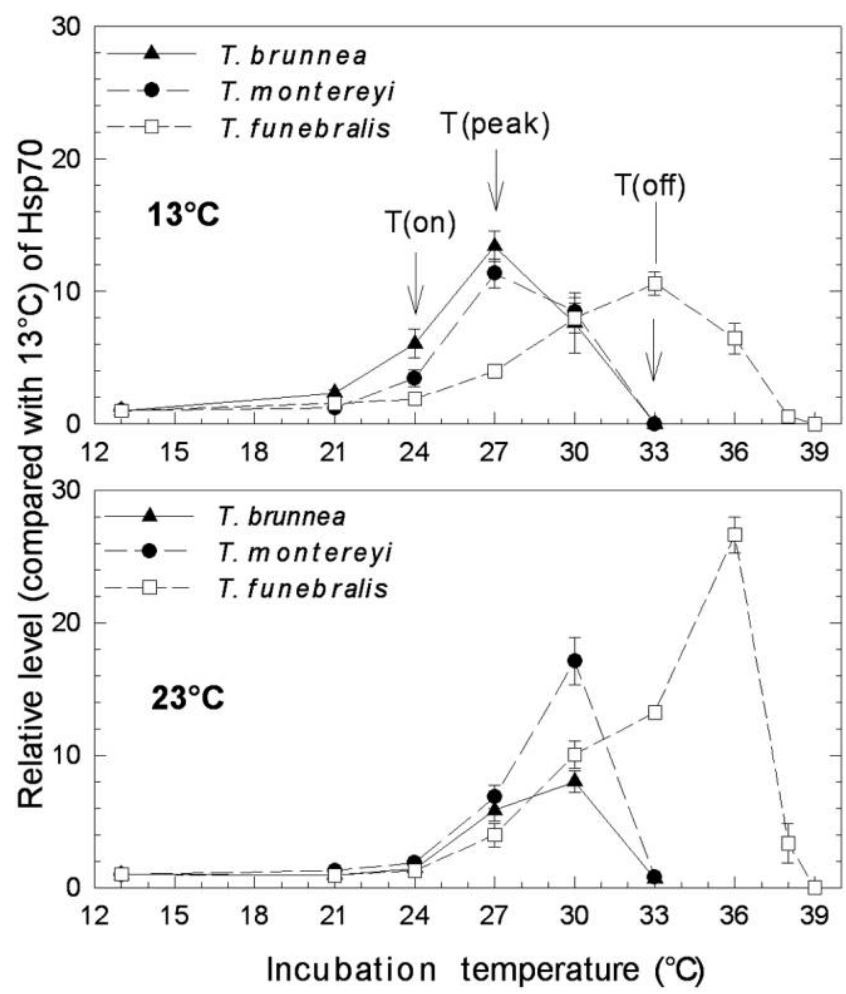

Figure 2. Relative induction (compared with the $13^{\circ} \mathrm{C}$ control) of Hsp70 in the three temperate Tegula congeners Tegula funebralis, Tegula brunnea, and Tegula montereyi after acclimation to $13^{\circ}$ and $23^{\circ} \mathrm{C}$ for 30-34 d; $T_{\text {on }}$ indicates the onset temperature, $T_{\text {peak }}$ indicates the temperature of maximal induction, and $T_{\text {off }}$ indicates the cessation temperature of Hsp synthesis. Data are means \pm 1 SEM $(N=5)$ for all data points except for $13^{\circ} \mathrm{C}$-acclimated T. funebralis at $36^{\circ} \mathrm{C}, 23^{\circ} \mathrm{C}$ acclimated T. funebralis at $33^{\circ} \mathrm{C}$, and T. brunnea at $13^{\circ} \mathrm{C}$. (Modified after Tomanek and Somero 1999.)

uated how elevated temperatures modify the stress response (Fig. 2). The increase in acclimation temperature from $13^{\circ}$ to $23^{\circ} \mathrm{C}$ did not modify $T_{\text {on }}$ and $T_{\text {off }}$ of Hsp70 synthesis in $T$. funebralis $\left(T_{\text {on }}=27^{\circ} \mathrm{C}\right) ; T_{\text {peak }}$, however, shifted from $33^{\circ}$ to $36^{\circ} \mathrm{C}$. In contrast, both $T_{\text {on }}$ and $T_{\text {peak }}$ of Hsp70 synthesis increased by $3^{\circ} \mathrm{C}$ in $T$. brunnea and T. montereyi; $T_{\text {off }}$, however, did not shift. These changes were confirmed using twodimensional gel electrophoresis (Fig. 4; Tomanek 2005).

The results of these studies illustrate that the acclimation ability of the more eurythermal intertidal Tegula congener is limited, probably because it is already living close to the highest temperatures it can tolerate. Tegula brunnea and T. montereyi rarely if ever experience body temperatures of $24^{\circ} \mathrm{C}$ or higher, the $T_{\text {on }}$ of Hsp70 synthesis in these congeners, and therefore are unlikely to activate the response under natural conditions (Fig. 1). In contrast, T. funebralis activates the HSR at $27^{\circ} \mathrm{C}$, a temperature it experienced for at least several hours on onethird of the days during a month-long measurement of body temperatures in the spring at a central Californian location (Tomanek and Somero 1999).

The above discussion focuses on $T_{\text {on }}$ rather than on $T_{\text {off }}$, the upper temperature at which Hsps are synthesized, as a physiological measure of plasticity caused by acclimation for two reasons. First, $T_{\text {off }}$ is higher than $T_{\text {on }}$ (by $9^{\circ}$ and $11^{\circ} \mathrm{C}$ in $13^{\circ} \mathrm{C}$ acclimated specimens) and therefore less relevant under natural conditions. Second, at any temperature above $T_{\text {peak }}$, Hsp synthesis cannot match the increasing cellular thermal insult, again suggesting that $T_{\text {off }}$ 's relevance is limited under natural conditions even if acute thermal tolerance $\left(\mathrm{LT}_{50}\right)$ correlates closely with $T_{\text {off }}$ (Tomanek and Somero 1999). It is interesting, however, that $T_{\text {off }}$ values are fixed between species and did not change with acclimation to higher temperatures.

The above data show that T. funebralis has limited ability to modify Hsp synthesis in response to acute heat stress during acclimation to elevated temperatures in comparison with $T$. brunnea and T. montereyi (for another intertidal invertebrate example, the barnacle Balanus glandula, see Berger and Emlet 2007). Similarly, T. funebralis can only narrowly adjust standing-stock levels of two Hsp70 bands, Hsp90 and the HSF1, components of the chaperone transcription factor complex thought to regulate Hsp transcription (Tomanek and Somero 2002). On the other hand, the capacity of T. funebralis to synthesize Hsps over a wider temperature range (Fig. 2), to recover from a heat shock at a faster rate (Tomanek and Somero 2000), and to cope with the thermally more variable conditions in the midintertidal zone better (Tomanek and Sanford 2003) all show that it is adapted to a wider range of thermal conditions than its two subtidal congeners. Thus, in Tegula congeners, the increased tolerance to heat correlates positively with the thermal range of Hsp synthesis and negatively with the ability to further modify the HSR. A similar pattern has been found that suggests that heart rate function, too, is modified more in low-intertidal to subtidal than in midintertidal congeners of the porcelain crab genus Petrolisthes (Stillman and Somero 2000) and of Tegula (Stenseng et al. 2005).

If the function of the acclimation response is to protect the organism from the possibility that the environment will become even hotter, as speculated (Leroi et al. 1994; Huey et al. 1999), a limited capacity to acclimate the HSR may simply be a consequence of the greater ability to cope with a wider range of temperatures. This limited capacity to acclimate Hsp synthesis suggests a possible cellular explanation for the limited ability of more heat-tolerant organisms to further increase tolerance to even greater heat stress (Ushakov et al. 1977; Hoffmann et al. 2003; Stillman 2003). A limited capacity to modify Hsp synthesis in heat-tolerant organisms in response to heat stress has consequences for how species with varying adaptation temperatures will respond to increasing temperatures due to global climate change. Although more eurythermal species are poised to cope better with thermal extremes under current climate conditions, their physiological limits are already close to the highest body temperatures they experience, and they have a limited capacity to modify these limits further, thus making them particularly vulnerable to any further increase in temperature (Fig. 1). 

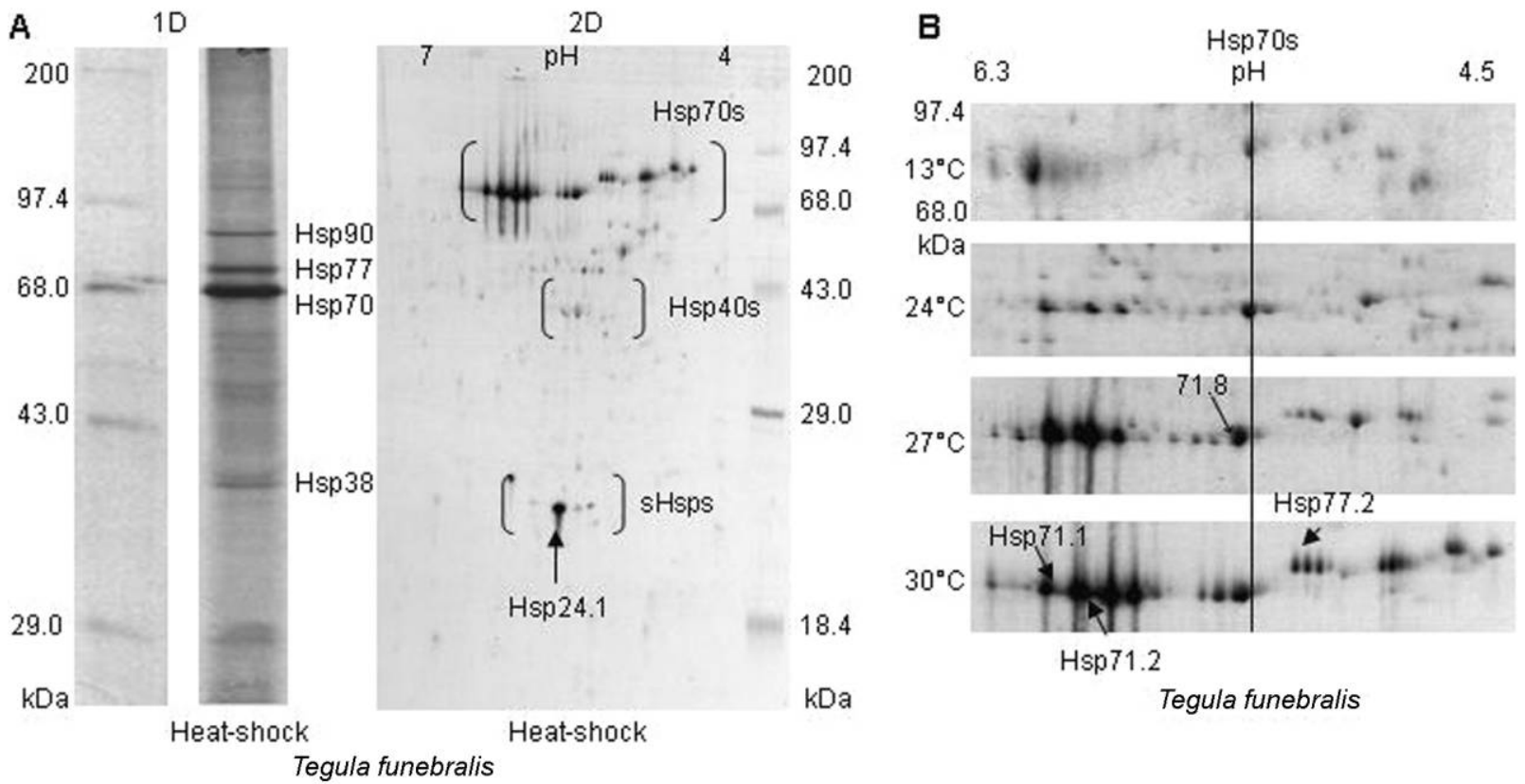

Figure 3. Autoradiographs of ${ }^{35} \mathrm{~S}$-labeled proteins $(A)$ following incubation to $30^{\circ} \mathrm{C}$ (heat shocked) for $2.5 \mathrm{~h}$ and $4 \mathrm{~h}$ of recovery (and labeling) at $13^{\circ} \mathrm{C}$ in gill tissues of $13^{\circ} \mathrm{C}$-acclimated Tegula funebralis after one-dimensional (1D) and two-dimensional (2D) gel analysis. Clusters of heatinduced proteins are indicated in $A$. B, Heat-induced activation of synthesis of proteins between $70-90 \mathrm{kDa}$ in $13^{\circ} \mathrm{C}$-acclimated $T$. funebralis. The constitutively expressed protein spot Hsp71.8 is always found to the left of the vertical line. Synthesis levels of Hsp71.1 (A) are shown in Figure 4. The ${ }^{14} \mathrm{C}$ molecular mass markers are shown on the side of the gels (A). (Modified after Tomanek 2005.)

\section{Geographic Variation of the Heat-Shock Response and Global Climate Change}

Species' ranges are moving toward the poles due to climate change (Parmesan 2006), suggesting that populations at the southern edges (in the Northern Hemisphere) are experiencing a greater level of stress as well as greater competition from more warm-adapted species. Although some studies on intertidal organisms show higher levels of Hsp70 toward the southern limits versus the center of an animal's distribution range (Sorte and Hofmann 2004), other studies show a reverse or a more complex pattern (Osovitz and Hofmann 2005; Sagarin and Somero 2006) and thus support the hypothesis that the patterns of thermal stress in the intertidal zone along the Pacific coast of North America may coincide with daytime occurrence of low tides rather than a latitudinal thermal cline (Helmuth et al. 2002).

Although populations at the southern range limits or in locations that see daytime low-tide extremes are expected to live closer to their upper thermal limits, specimens from cooler subtidal environments within the range of a species tend to be more sensitive to heat shock, which is reflected in higher levels of induced Hsp and transcript (Osovitz and Hofmann 2005; Fangue et al. 2006). So where are thermal extremes affecting populations the most: in colder areas, where animals are more sensitive to heat stress, or in warmer areas, where animals live closer to their thermal limits? Nothing so far suggests that colder populations, although more sensitive to heat stress, can- not acclimatize to warmer conditions. In contrast, populations from warmer regions may be limited in their ability to acclimate to even warmer conditions, especially in intertidal organisms. Although there are costs associated with acclimating or acclimatizing to more extreme thermal conditions, it is likely that reaching the upper thermal limits presents a greater risk of affecting populations. The balance between these two risks (or costs) to an organism's fitness is likely to differ between subtidal and intertidal species.

\section{Conclusion}

How are physiological temperature limits determining the response of organisms to global climate change? Studies on the HSR, its evolutionary variation, and ecological importance show one surprising outcome: some of today's most eurythermal organisms may be at a great risk of being the most affected by an increase in temperature. The extent to which physiological systems as a whole will limit the ability of organisms to cope with increasing thermal stress, however, remains unclear. We will be able to address this uncertainty by applying a systems approach, using transcriptomics and proteomics tools that can provide us with a more comprehensive perspective of physiological changes to temperature (Tomanek 2005; Teranishi and Stillman 2007). Additionally, in order to understand the comprehensive organismal response to global climate change, we will have to study how abiotic and biotic factors interact by integrating ecological and physiological research programs in 

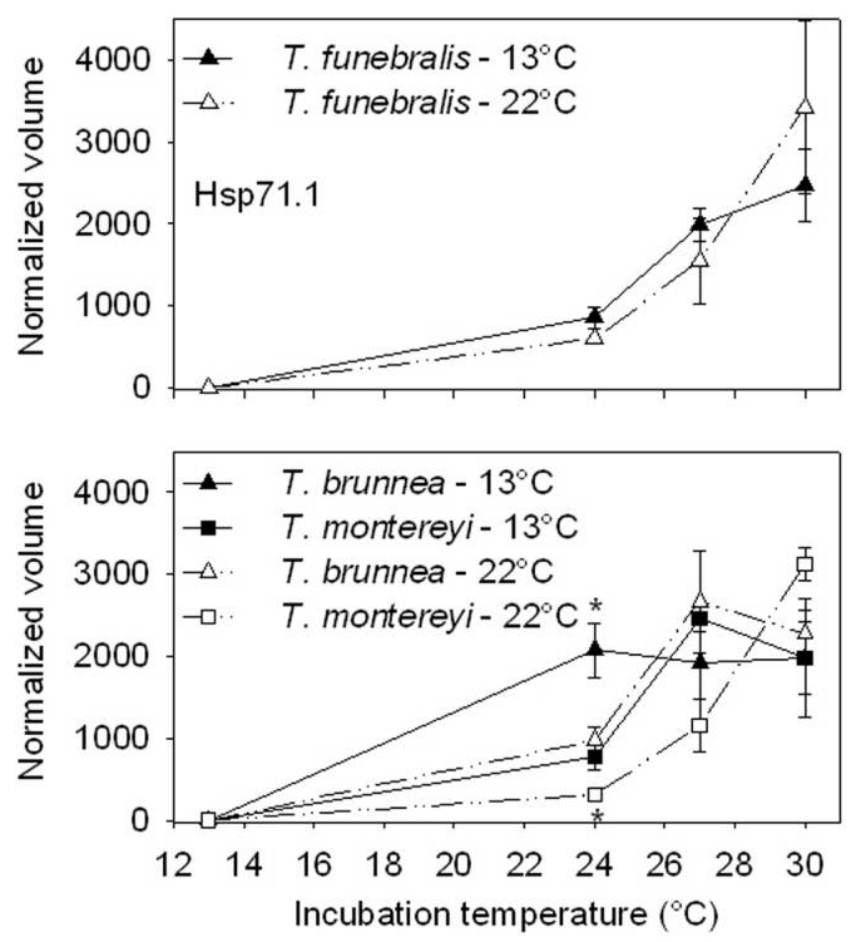

Figure 4. Normalized volumes (relative to total spot volume) of acute synthesis of Hsp71.1 in response to temperature in $13^{\circ}$ - and $22^{\circ} \mathrm{C}$ acclimated specimens of Tegula funebralis, Tegula brunnea, and Tegula montereyi. Shown are means \pm 1 SEM. An asterisk near a symbol (above or below) indicates a statistically significant interaction effect $(P \leq 0.05$ or $P \leq 0.10)$ between acclimation $\left(13^{\circ}\right.$ and $\left.22^{\circ} \mathrm{C}\right)$ and incubation $\left(24^{\circ}, 27^{\circ}\right.$, or $\left.30^{\circ} \mathrm{C}\right)$ temperature for this species. (Modified after Tomanek 2005.)

a collaborative research effort (Harley et al. 2006). Matching systems biology with the real world may be the most challenging and revealing path for development of accurate predictions of how organisms will respond to a warming planet.

\section{Acknowledgments}

Work presented in this article was supported by National Science Foundation grants (IBN 0133184, IOB 0717087) to Dr. George Somero at Hopkins Marine Station of Stanford University and to L.T. at Cal Poly San Luis Obispo as well as by the David and Lucile Packard Foundation. Two anonymous reviewers contributed critical comments that greatly helped improve the article. Thanks to Dr. Peter Fields for helpful edits and critical comments.

\section{Literature Cited}

Barnett T.P., D.W. Pierce, K.M. AchutaRao, P.J. Gleckler, B.D. Santer, J.M. Gregory, and W.M. Washington. 2005. Penetration of human-induced warming into the world's ocean. Science 309:284-287.

Barry J.P., C.H. Baxter, R.D. Sagarin, and S.E. Gilman. 1995.
Climate-related, long-term faunal changes in a Californian rocky intertidal community. Science 267:672-675.

Barua D. and S.A. Heckathorn. 2004. Acclimation of the temperature set-points of the heat-shock response. J Therm Biol 29:185-193.

Berger M.S. and R.B. Emlet. 2007. Heat-shock response of the upper intertidal barnacle Balanus glandula: thermal stress and acclimation. Biol Bull 212:232-241.

Bosch T.C.G., S.M. Krylow, H.R. Bode, and R.E. Steele. 1988. Thermotolerance and synthesis of heat shock proteins: these responses are present in Hydra attenuata but absent in Hydra oligactis. Proc Natl Acad Sci USA 85:7927-7931.

Buckley B.A., M.-E. Owen, and G.E. Hofmann. 2001. Adjusting the thermostat: the threshold induction temperature for the heat-shock response in intertidal mussels (genus Mytilus) changes as a function of thermal history. J Exp Biol 204: 2816-2829.

Burg M.B. and J.D. Ferraris. 2008. Intracellular organic osmolytes: function and regulation. J Biol Chem 283:73097313.

Carlton J.T. 2007. The Light and Smith Manual: Intertidal Invertebrates from Central California to Oregon. University of California Press, Berkeley.

Dietz T.J. and G.N. Somero. 1992. The threshold induction temperature of the $90-\mathrm{kDa}$ heat shock protein is subject to acclimatization in eurythermal goby fishes (genus Gillichthys). Proc Natl Acad Sci USA 89:3389-3393.

. 1993. Species and tissue-specific synthesis patterns for heat-shock proteins HSP70 and HSP90 in several marine teleost fishes. Physiol Zool 66:863-880.

Fangue N.A., M. Hofmeister, and P.M. Schulte. 2006. Intraspecific variation in thermal tolerance and heat shock protein gene expression in common killifish, Fundulus heteroclitus. J Exp Biol 209:2859-2872.

Feder M.E. and G.E. Hofmann. 1999. Heat shock proteins, molecular chaperones, and the stress response: evolutionary and ecological physiology. Annu Rev Physiol 61:243-282.

Feige U., R.I. Morimoto, I. Yahara, and B.S. Polla, eds. 1996. Stress Inducible Cellular Responses. Birkhäuser, Basel.

Frydman J. 2001. Folding of newly translated proteins in vivo: the role of molecular chaperones. Annu Rev Biochem 70: 603-649.

Gellner K., G.A. Praetzel, and T.C.G. Bosch. 1992. Cloning and expression of a heat-inducible hsp70 gene in two species of Hydra which differ in their stress response. Eur J Biochem 210:683-691.

Halpin P.M., C.J.B. Sorte, G.E. Hofmann, and B.A. Menge. 2002. Patterns of variation in levels of Hsp70 in natural rocky shore populations from microscales to mesoscales. Integr Comp Biol 42:815-824.

Hamdoun A.M., D.P. Cheney, and G.N. Cherr. 2003. Phenotypic plasticity of HSP70 and HSP70 gene expression in the Pacific oyster (Crassostrea gigas): implications for thermal limits and induction of thermal tolerance. Biol Bull 205:160169. 
Harley C.D.G., A.R. Hughes, K. Hultgren, B.G. Miner, C.J.B. Sorte, C.S. Thornber, L.F. Rodrigues, L. Tomanek, and S.L. Williams. 2006. The impacts of climate change in coastal marine systems. Ecol Lett 9:228-241.

Hartl F.U. and M. Hayer-Hartl. 2002. Molecular chaperones in the cytosol: from nascent chain to folded protein. Science 295:1852-1858.

Helmuth B., C.D.G. Harley, P.M. Halpin, M. O’Donnell, G.E. Hofmann, and C. Blanchette. 2002. Climate change and latitudinal patterns of intertidal thermal stress. Science 298: 1015-1017.

Helmuth B.S. and G.E. Hofmann. 2001. Microhabitats, thermal heterogeneity, and patterns of physiological stress in the rocky intertidal zone. Biol Bull 201:374-384.

Helmuth B.S.T. 1999. Thermal biology of rocky intertidal mussels: quantifying body temperatures using climatological data. Ecology 80:15-34.

Hochachka P.W. and G.N. Somero. 2002. Biochemical adaptation: mechanism and process in physiological evolution. Oxford University Press, Oxford.

Hoffmann A.A., J. Sorensen, and V. Loeschke. 2003. Adaptation of Drosophila to temperature extremes: bringing together quantitative and molecular approaches. J Therm Biol 28:175216.

Hofmann G.E., B.A. Buckley, S. Airaksinen, J.E. Keen, and G.N. Somero. 2000. Heat-shock protein expression is absent in the antarctic fish Trematomus bernacchii (family Nototheniidae). J Exp Biol 203:2331-2339.

Hofmann G.E., S.G. Lund, S.P. Place, and A.C. Whitmer. 2005. Some like it hot, some like it cold: the heat shock response is found in New Zealand but not in Antarctic notothenioid fishes. J Exp Mar Biol Ecol 316:79-89.

Hofmann G.E. and G.N. Somero. 1995. Evidence for protein damage at environmental temperatures: seasonal changes in levels of ubiquitin conjugates and hsp70 in the intertidal mussel Mytilus trossulus. J Exp Biol 198:1509-1518.

- 1996a. Interspecific variation in thermal denaturation of proteins in the congeneric mussels Mytilus trossulus and M. galloprovincialis: evidence from the heat-shock response and protein ubiquitination. Mar Biol 126:65-75.

- 1996b. Protein ubiquitination and stress protein synthesis in Mytilus trossulus occurs during recovery from tidal emersion. Mol Mar Biol Biotechnol 5:175-184.

Huey R.B., D. Berrigan, G.W. Gilchrist, and J.C. Herron. 1999. Testing the adaptive significance of acclimation: a strong interference approach. Am Zool 39:323-336.

IPCC (Intergovernmental Panel on Climate Change). 2007. Climate Change 2007: The Physical Science Basis. Cambridge University Press, Cambridge.

Leroi A.M., A.F. Bennett, and R.E. Lenski. 1994. Temperature acclimation and competitive fitness: an experimental test of the beneficial acclimation assumption. Proc Natl Acad Sci USA 91:1917-1921.

Levitus S., J. Antonov, and T. Boyer. 2005. Warming of the world ocean, 1955-2003. Geophys Res Lett 32:L02604.
Morimoto R.I. 1998. Regulation of the heat shock transcriptional response: cross talk between a family of heat shock factors, molecular chaperones, and negative regulators. Genes Dev 2:3788-3796.

Nakano K. and G.K. Iwama. 2002. The 70-kDa heat shock protein response in two intertidal sculpins, Oligocottus maculosus and O. snyderi: relationship of hsp70 and thermal tolerance. Comp Biochem Physiol A 133:79-94.

Osovitz C.J. and G.E. Hofmann. 2005. Thermal historydependent expression of the hsp70 gene in purple sea urchins: biogeographic patterns and the effect of temperature acclimation. J Exp Mar Biol Ecol 327:134-143.

Parmesan C. 2006. Ecological and evolutionary responses to recent climate change. Annu Rev Ecol Evol Syst 37:637-669.

Petricorena Z.L. and G.N. Somero. 2007. Biochemical adaptations of notothenioid fishes: comparisons between cold temperate South American and New Zealand species and antarctic species. Comp Biochem Physiol A 147:799-807.

Pierce D.W., T.P. Barnett, K.M. AchutaRao, P.J. Gleckler, J.M. Gregory, and W.M. Washington. 2006. Anthropogenic warming of the oceans: observations and model results. J Clim 19: 1873-1900.

Pörtner H.O. and R. Knust. 2007. Climate change affects marine fishes through the oxygen limitation of thermal tolerance. Science 315:95-97.

Riedman M.L., A.H. Hines, and J.S. Pearse. 1981. Spatial segregation of four species of turban snails (genus Tegula) in central California. Veliger 24:97-102.

Roberts D.A., G.E. Hofmann, and G.N. Somero. 1997. Heatshock protein expression in Mytilus californianus: acclimatization (seasonal and tidal-height comparisons) and acclimation effects. Biol Bull 192:309-320.

Root T.L., J.T. Price, K.R. Hall, S.H. Schneider, C. Rosenzweig, and J.A. Pounds. 2003. Fingerprints of global warming on wild animals and plants. Nature 421:57-60.

Sagarin R.D. and G.N. Somero. 2006. Complex patterns of expression of heat-shock protein 70 across the southern biogeographical ranges of the intertidal mussel Mytilus californianus and snail Nucella ostrina. J Biogeogr 33:622-630.

Sanders B.M., C. Hope, V.M. Pascoe, and L.S. Martin. 1991. Characterization of stress protein response in two species of Colisella limpets with different temperature tolerances. Physiol Zool 64:1471-1489.

Somero G.N. 1995. Proteins and temperature. Annu Rev Physiol 57:43-68.

-2004. Adaptation of enzymes to temperature: searching for basic "strategies." Comp Biochem Physiol B 139:321333.

Sorte C.J.B. and G.E. Hofmann. 2004. Changes in latitude, changes in aptitudes: Nucella canaliculata (Mollusca: Gastropoda) is more stressed at its range edge. Mar Ecol Prog Ser 274:263-268.

- 2005. Thermotolerance and heat-shock protein expression in northeastern Pacific Nucella species with different biogeographical distribution ranges. Mar Biol 146:985-993. 
Stenseng E., C.E. Braby, and G.N. Somero. 2005. Evolutionary and acclimation-induced variation in the thermal limits of heart function in congeneric marine snails (genus Tegula): implications for vertical zonation. Biol Bull 208:138-144.

Stillman J.H. 2003. Acclimation underlies susceptibility to climate change. Science 301:65.

Stillman J.H. and G.N. Somero. 2000. A comparative analysis of the upper thermal tolerance limits of eastern Pacific porcelain crabs, genus Petrolisthes: influences of latitude, vertical zonation, acclimation, and phylogeny. Physiol Biochem Zool 73:200-208.

Sutton R.T., B. Dong, and J.M. Gregory. 2007. Land/sea warming ratio in response to climate change: IPCC AR4 model results and comparison with observations. Geophys Res Lett 34:L02701.

Teranishi K.S. and J.H. Stillman. 2007. A cDNA microarray analysis of the response to heat stress in hepatopancreas tissue of the porcelain crab Petrolisthes cinctipes. Comp Biochem Physiol D 2:53-62.

Todgham A.E., G.K. Iwama, and P.M. Schulte. 2006. Effects of the natural tidal cycle and artificial temperature cycling on Hsp levels in the tidepool sculpin Oligocottus maculosus. Physiol Biochem Zool 79:1033-1045.

Tomanek L. 2002. The heat-shock response: its variation, regulation and ecological importance in intertidal gastropods (genus Tegula). Integr Comp Biol 42:797-807.

- 2005. Two-dimensional gel analysis of the heat-shock response in marine snails (genus Tegula): interspecific variation in protein expression and acclimation ability. J Exp Biol 208:3133-3143.

Tomanek L. and E. Sanford. 2003. Heat-shock protein 70
(Hsp70) as a biochemical stress indicator: an experimental field test in two congeneric intertidal gastropods (genus: Tegula). Biol Bull 205:276-284.

Tomanek L. and G.N. Somero. 1999. Evolutionary and acclimation-induced variation in the heat-shock responses of congeneric marine snails (genus Tegula) from different thermal habitats: implications for limits of thermotolerance and biogeography. J Exp Biol 202:2925-2936.

- 2000. Time course and magnitude of synthesis of heatshock proteins in congeneric marine snails (genus Tegula) from different tidal heights. Physiol Biochem Zool 73:249256.

. 2002. Interspecific and acclimation-induced variation in levels of heat-shock proteins 70 (hsp70) and 90 (hsp90) and heat-shock transcription factor-1 (HSF1) in congeneric marine snails (genus Tegula): implications for regulation of $h s p$ gene expression. J Exp Biol 205:677-685.

Ushakov B.P., I.S. Asomova, I.S. Chernokozheva, I.N. Dregolskaya, I.M. Pashkova, and E.D. Skholl. 1977. The environmental temperature and physiological polymorphism of populations. II. J Therm Biol 2:9-15.

Walther G.R., E. Post, P. Convey, A. Menzel, C. Parmesan, T.J. Beebee, J.M. Fromentin, O. Hoegh-Guldberg, and F. Bairlein. 2002. Ecological responses to recent climate change. Nature 416:389-395.

Yancey P.H. 2005. Organic osmolytes as compatible, metabolic and counteracting cytoprotectants in high osmolarity and other stresses. J Exp Biol 208:2819-2830.

Zakhartsev M., B. De Wachter, T. Johnasen, H.O. Portner, and R. Blust. 2005. Hsp70 is not a sensitive indicator of thermal limitation in Gadus morhua. J Fish Biol 67:767-778. 